\title{
The use of local stone in the buildings of the Isle of Wight
}

\author{
Dr G. K. Lott
}

\begin{abstract}
The charm of the Isle of Wight, so much appreciated by visitors and the local population alike, is very much a combination of its delightful scenery and unique assemblage of vernacular buildings. These buildings range from isolated farmhouses to elaborate manor houses, castles and churches all constructed using the indigenous stone resources of the island. Today, these stone buildings, many of which date back to medieval times, are increasingly in need of conservation repair to maintain them for future generations. Essential to such conservation work is the safeguarding of the island's indigenous building stone sources as many of the stones used are unique to the island and no longer quarried. Protecting these stone sources could also provide stone for new building projects which would help to further enhance the character of the island's towns and villages.
\end{abstract}

\section{Introduction}

The Isle of Wight has a diverse stone built heritage that has perhaps not received, with the exception of the ground-breaking study of the local vernacular architecture by Marion Brinton and colleagues (1987), the attention it deserves in the general literature. Local guidebooks and the ubiquitous annual calenders often tend to focus on the admittedly attractive 'chocolate-box' picturesque houses (e.g. Brighstone village and Winkle Street, Calbourne) or the grander properties like Appuldurcombe House, rather than reflect on the less obtrusive, but much richer stone-built heritage that exists in towns and villages throughout the island. The relative isolation of the island has meant that almost all the building stone used in the Isle of Wight, from at least Roman times, has been locally quarried and, unlike many other areas of the UK, has been relatively well preserved. There are few parts of the island's diverse geological succession that have not supplied local stone, brick clay or other building material, of one sort or another for construction purposes. During some periods of its history the island became an important exporter of building stone supplying many major medieval building projects on the adjacent mainland and was even providing building stone (Quarr Stone see below) for a number of famous buildings in the London area from the $11^{\text {th }}$ century (Tatton-Brown, 1980). It seems that the quality of the limestone and coastal location of the quarries at Binstead made it both feasible and 
presumably financially lucrative to transport the stone well beyond what might be imported into south eastern England at this time such as Caen Stone from France.

\section{The Geological Succession (Figure 2)}

The geological succession and structure of the Isle of Wight has always been a magnet for field geologists and it has been described in numerous geological guides and publications beginning in the early decades of the $19^{\text {th }}$ century and continuing to the present day. Published reviews of the island's stratigraphy, with comprehensive lists of early publications, include White (1921, $5^{\text {th }}$ Impression 1994 with expanded Bibliography and References by Edwards, R.A.), Insole et al. (1998), Hopson et al. (this volume). Perhaps the only drawback to this vast array of historic literature has been the tendency for the regular revision of the stratigraphical names used to describe the units and the often changing definition of their boundaries, as new geological techniques and interpretations have developed, a process which continues to the present day (compare, for example, Curry et al. 1978; Insole et al. 1998 and this volume).

In contrast, very few of the published books and papers, have provided more than a limited amount of information about the detailed use of the local stone for building purposes across the island. Among the principal exceptions are the early memoirs published by the Geological Survey beginning with Bristow et al. (1889) and ending with White (1921).

The island can be divided conveniently into two geographical areas lying to the north and south of the prominent Upper Cretaceous Chalk upland area that forms the central ridge, the Sandown and Brighstone anticlinal axes, of the island (Fig. 1). To the north of these axes the succession is dominated by the youngest rocks of the island which comprise the mudstone and limestone-dominated intervals of the Palaeogene (early Tertiary), while to the south of these Chalk axes, the rock successions are dominated by the lithologically much more varied sequences (sandstones, limestones, ironstones and mudstones) of the Lower Cretaceous.

Geologically, the oldest rocks cropping out in the island lie to the south of the axial area and comprise the fluvio-lacustrine rocks of the Wealden Group of early Cretaceous age (Fig. 2). Like much of the rock succession of the island they are well exposed only in coastal sections and, where they are seen at outcrop, they are 
dominated by clay and mudstone-rich lithologies. However, within these fine-grained successions are occasional thin, hard, fossiliferous limestone, coarse-grained sandstone and occasional conglomeratic beds.

In contrast, the conformably overlying shallow marine, Lower Greensand Group (Aptian-Albian) succession, which crops out extensively over much of the remainder of the southern half of the island, is typically coarser grained and characteristically highly ferruginous in character. This group includes the thin basal, clay-dominated Atherfield Clay Formation which passes up into the coarser grained sandstone-dominated beds of the Ferruginous Sands, Sandrock and Monk's Bay Sandstone (Carstone) formations.

A gradual change in the overall lithological character of the succession becomes apparent in the overlying beds, with the development of more open marine deposition characterised first by the clay-dominated Gault Clay Formation and, subsequently, by the overlying glauconite-rich, siliceous sandstones and sandy limestones of the Upper Greensand Formation. Together these formations make up the newly defined Selborne Group (Hopson et al., 2008). The hard, thinly-bedded, Upper Greensand outcrops are readily recognisable as they form a prominent topographical cap to many of the southern coastal cliffs and inland exposures. The Selborne Group also forms a continuous outcrop extensively along the southern edge of the central upland axes and also in the south part of the island.

The Selborne Group succession represents the coarsest grained sandstone in the Cretaceous succession of the Isle of Wight and the commencement of the finegrained chalky limestone dominated sedimentation that characterises the Upper Cretaceous Chalk Group succession. The principal Chalk Group outcrop extends from Culver Cliff in the east, to the Needles in the west, capping the high ground that forms the central upland axes of the island; a second outcrop forms much of the high ground of the south eastern part of the island from Shanklin Down in the east to St Catherine's Hill in the west (Figure 1). The steeply dipping Chalk Group succession of the axial area of the Isle of Wight ranges from Cenomanian to Campanian (Grey and White Chalk subgroups) in age while the thinner southern outcrop is restricted to chalks of Cenomanian to Turonian (Grey Chalk to lower White Chalk subgroups) age.

The end of open marine, chalk-dominated carbonate sedimentation of the Upper Cretaceous is followed in the Isle of Wight by a pause in sedimentation prior to the onset of Palaeogene (Lower Tertiary) deposition. A marked change to the 
lithologically, highly variable, clastic mud- and sand-dominated, marginal marine and Palaeogene, by marginal marine and terrestrial clastics and freshwater carbonatedominated sedimentation. These Palaeogene outcrops cover most the island to the north of the central upland axes and provide the best exposures of this succession in the UK and Europe (Daley 1999).

A major break in sedimentation related to a phase of tectonism (Alpine Orogeny) culminating in the Miocene then produced the main structural elements of the island as we see them today. Sedimentation recommenced in the Plio-Pleistocene with the deposition of the unconsolidated, coarse fluvial sediments that characterise the regional drainage systems that developed marginal to the glaciation front to the north.

\section{Building stone sources in the Isle of Wight}

Most of the suitable lithological units from the early Cretaceous to Oligocene rock succession in the Isle of Wight, supplemented locally by Pleistocene deposits, have been exploited as sources of vernacular building stone in the past. Lithologically they comprise a wide variety of sandstones, limestones and ironstones together with assorted chert and flint nodules and cobbles derived from the Upper Greensand and Chalk succession, or from the coarse superficial gravels that cover large parts of the island. However, much of the character of the stone buildings in the Isle of Wight is not due entirely to the variety of stone used, but also to the distinctive, local construction styles which are used in the houses. The almost ubiquitous occurrence of the coursed and 'galletted' wallstones in the Cretaceous sandstones, Chalks and Tertiary limestones is particulary characteristic of the island (e.g. Plate 1)

\section{Early Cretaceous building stones}

\section{Wealden Group (Wessex and Vectis formations)}

The succession is well exposed only in coastal sections in the southeast (Sandown Bay) and southwest (Brighstone Bay) of the island and is, as noted above, dominated by variegated clay and fissile mudstone-rich lithologies which have yielded many significant fish, reptilian and dinosaur fossils. However, also within these fine-grained successions occasional harder, thin limestones and coarser fossiliferous and conglomeratic beds occur which provided a local source of rubblestone, for building 
and decorative materials in the villages of Brook, Mottistone, Brighstone and Yafford in the west, and are occasionally evident in Sandown and the village of Yaverland on the eastern outcrop ( $c f$. Brinton 1987). Some of the thin, coarsely fossiliferous, brown, freshwater lagoonal limestone slabs (containing Filosina sp. or Viviparus infracretacicus), which are common on the beach at Sandown, were locally used as paving stone and are very similar in character to the fossiliferous or 'Paludina' limestones of the Wealden Group in the Weald area of south east England (Lewis, 1848).

Lower Greensand Group (Ferruginous Sands, Sandrock and Monk's Bay Sandstone formations)

Perhaps the most distinctive building stone resources in the southern part of the Isle of Wight, however, occur within the ferruginous successions of the Lower Greensand Group. While much of this succession is too fine-grained or poorly cemented to produce good building stone, villages across the outcrop still show extensive use of its more durable beds from both the paler, finer grained, yellow-orange-brown sandstones of the Ferruginous Sands and Sandrock formations and the distinctive dark, variegated, purple-red or red-brown 'ironstones' extracted from the hard Monk's Bay Sandstone Formation that caps the group. Good examples of their use as a building stone can be seen at Yarbridge, Knighton, Arreton, Whitcroft, Rockley, Chilerton, Shorwell, Wolverton, Brighstone, Mottistone, Hulverstone, Faringford and Locksley and along its southern outcrop in Wroxall, Luccombe, Whitwell and Blackgang. The finer grained sandstones are used both as uncoursed rubblestone blocks and as dressed ashlar, but the Monk's Bay Sandstone lithologies are most commonly seen as large, irregularly coursed, rubblestone blocks (Plate 1 A \& B). The intractable nature of these ironstones has meant that quoin stones, buttresses and window mouldings are commonly constructed in local brick or using the finer local sandstones (Upper Greensand Formation) which are more suitable for dressing as ashlar (Plate 1C \& D).

Petrography of the Lower Greensand Group building stones

Ferruginous Sands Formation 
The variegated, porous, paler coloured sandstones of this unit are dominated by finegrained, moderately well sorted quartz grains, with sporadic ferruginous clasts in patchy quartz and/or thin, ferruginous grain coating cements (Plate 2A).

\section{Sandrock Formation}

The sandstones of this unit are dominated by well sorted, fine-grained quartz grains, with subordinate glauconite, sparse potassic feldspar and mica grains which form an open, porous framework. The quartz grains are dominantly monocrystalline, subangular to angular grains. The grains generally show a narrow, grain-coating (illitic) cement.

\section{Monk's Bay Sandstone Formation (Carstone)}

The distinctive dark coloured, ferruginous sandstones of this unit are readily identified wherever they occur. In thin section they comprise poorly sorted, fine- to coarsegrained, quartz -dominated grain framework with sparse glauconite and potassic feldspar grains set in a pervasive, thick, opaque, finely pelletal (faecal), ferruginous matrix (Plate 2B).

\section{Selborne Group}

\section{Upper Greensand Formation}

This formation was the most important source of building sandstone on the island. It comprises pale greenish-grey, fine-grained, glauconitic, calcareous and siliceous sandstones with spicular cherts, which have been the source of the large ashlar stone block for many houses in the island (Plate 1C \& D). Extensive use of ashlared Upper Greensand can be seen for example at Shanklin, Newchurch, Rew, Niton, Whitwell, Newport (Carisbrooke), Gatcombe and Wroxall. The principal worked bed, commonly once known as the 'freestone' bed, is only in the order of $1.2-1.8 \mathrm{~m}$ in thickness but can be traced in the cliff and quarry sections along much of its outcrop (e.g. Jukes-Browne \& Hill 1900; White 1921). A particularly distinctive lithological or facies variant of the sandstone from this group was quarried between Bonchurch and Ventnor in the south and was termed Green Ventnor Stone because of the higher concentration of green glauconite grains present in the sandstones at this particular location (Plate 2C). The principal quarries were developed along the area known as the Undercliff, and some were still active in 1921 and even appear to have extended their workings underground in places. Some of these quarries were subsequently occupied by the railway station and sidings at Ventnor. Large blocks of Green 
Ventnor ashlar are common in houses in the town and in surrounding villages. The from early times e.g Appuldercombe House $\left(18^{\text {th }} \mathrm{C}\right)$, Arreton $\left(17^{\text {th }} \mathrm{C}\right)$ and Yaverland $\left(17^{\text {th }} \mathrm{C}\right)$ manors. The coastal location of the quarries also readily facilitated export of the stone to the mainland for use along with Quarr Stone (and several other stones) in Winchester Cathedral (Tatton-Brown 1993). In contrast, Tomalin $(2002,2003)$ has discussed working of the sandstones from the Upper Greensand Formation for construction at Carisbrooke Castle, identifying former quarries at Vayres Farm and Gat Cliff as important sources of local building sandstone since pre-Norman times.

\section{Petrography of the Upper Greensand Formation building stones}

In thin section the sandstones generally comprise a framework of fine- to mediumgrained quartz, with subordinate glauconite and bioclastic debris (including foraminifera, sponge spicules) and a variable, micromicaceous matrix. Bioturbation is a common feature in some fabrics. The sandstones may be cemented by both micritic calcite or silica cements (Plate 2C). When weathered the sandstones can become highly porous as the vulnerable siliceous spicules are gradually leached out. Concentrations of siliceous sponge spicules has lead to the development of extensive chert (siliceous) lenses and laterally continuous, undulating thin beds, particularly in the upper part of the unit (Plate 2D). Occasionally, isolated lenses and nodules of chert, and some siliceous burrowfills can be seen in some Upper Greensand wall fabric blocks, but in general the thicker chert beds are only rarely used as wall stones with the softer, glauconitic sandy facies preferred as a general building stone.

\section{Late Cretaceous building stones}

\section{Chalk Group}

The hard, white chalk limestones of the Upper Cretaceous Chalk Group are one of the most distinctive and easily recognised building stones of the island. Houses, barns, farms and churches on and adjacent to the chalk outcrops of the central and southern outcrop areas were commonly, at least in part, constructed using chalk block. There is some marked variability in its use with random rubble and polygonal chalk rubblestone patterns common in some cottages, while in others coursed and squared, ashlar chalk blocks were preferred. Examples of the different chalk building fabrics that can occur can be seen in Havenstreet, Newchurch, Winford Cross, Mottistone and 
particularly Brighstone villages. Occasionally in some buildings (e.g. Barnsley Farm, e.g. Cladoceramus unduloplicatus, a marker for the top of the Seaford Chalk Formation (Base Santonian).

In addition to their importance as a source of this hard white Chalk building stones, the Upper Cretaceous (Turonian to Campanian) successions also yielded flint nodules which are a common feature in some houses in parts of the outcrop. Some of these flints, however, will not have been derived directly from the Chalk but were probably quarried from the gravel beds of the later Palaeogene strata or hand-picked from the post-glacial superficial sediment cover including the ubiquitous beach gravels. There are many examples of the use of these reworked, rounded or dressed flint nodules around the island, most notably at Ventnor and Calbourne.

\section{Petrography of the Upper Cretaceous building stones}

The distinctive, tectonized, hard, white chalk building stones of the Isle of Wight are lithologically quite varied in character both in outcrop, in buildings and under the microscope. Petrographically they comprise micritic limestones with variable proportions of comminuted, fine, bioclastic debris including planktonic and benthonic foraminifera, thin-walled bivalves and phosphatic grains in a pervasive non-ferroan micritic carbonate matrix.

\section{Palaeogene (Paleocene, Eocene and Oligocene) building stones}

The principal building stone resources of the Palaeogene succession are the pale grey, fossiliferous, freshwater limestone beds of the Bembridge Limestone and Headon Hill formations that crop out extensively along the northern and eastern coasts of the island. These limestone developments (which have a maximum thickness $c .9 \mathrm{~m}$ in the Bembridge Limestone Formation), occur only in the Isle of Wight area. The beds were extensively quarried east of Alum Bay at Headon Hill, where the numerous large fallen blocks were apparently once worked (Lewis, 1848), and also at Quarr, Binstead, Gurnard (Cowes) and St Helen's (Bembridge) (Colvin et al. 1982). In the latter area the worked limestone beds form a series of ledges at sea level. The quarrying of Bembridge Limestone at Gurnard (west of Cowes) and St Helen's for construction of fortifications at Portsmouth is documented from 1562 (Colvin et al 1982). 
A range of different lithologies were quarried from these limestone beds and in villages such as Calbourne, Shalfleet, Newtown and Totland. Numerous other historic buildings on the island also used Bembridge Limestone in their construction (Yarmouth Castle, Quarr Abbey, Arreton Church). The quarries in the Binstead area were briefly mentioned by Mantell (1847) who noted several active quarries varying in depth from 10 to 20 feet $(3-6.1 \mathrm{~m})$.

Perhaps the most famous of these Bembridge 'limestones' is the so-called Quarr Stone (or Featherbed Limestone) which was taken from a lithologically very distinctive unit composed of layers of closely packed, bioturbated, broken and abraded mollusc shells - shell brash or ragstone. The distinctive fabric of the rock and its durability made it an excellent freestone and it was often preferred for use in decorative mouldings and quoins rather than for general walling stone (Tatton-Brown 1980). However, the precise stratigraphic interval from which the Quarr Stone facies came has proved to be difficult to define (see Anderson and Quirk 1964), in part because the 'bed' was of clearly of restricted extent and by the end of the 15th century was largely worked out. There is no exposure of this facies in the Binstead area today. It is likely that the heavily quarried 'hills and holes' area east of Quarr Abbey and encompassed by Binstead, Quarr Wood and Holy Cross Church,was the principal source area of the Quarr Stone. The surviving walls of the abbey grounds and the local church contain significant proportions of the Quarr Stone, but in general its use in the island as a whole does not perhaps compare with the volumes exported and used on the mainland, most notably in the façade of Winchester Cathedral (TattonBrown, 1993), Chichester Cathedral and sporadically at both the cathedral and castle at Canterbury. Quarr Stone has also been identified in numerous Hampshire churches at for example at Boarhunt, Corhampton, Headborne Worthy and Little Somborne (Page, 1912: Potter, 2006).

The common association in the building stone literature of Quarr Stone with the original Cistercian medieval abbey at Quarr raises some interesting questions. The abbey was founded in 1132 and dissolved in 1537 and was named because of the quarries located closeby. These Binstead quarries are documented as having been producing limestone for mainland buildings since pre-Conquest times (Hockey, 1970). As a result of the dissolution there is now little to be seen of the abbey above ground. Archaeological evidence, however, confirms the abbey complex was of 
considerable extent with the church alone comprising a substantial, almost cathedrallike structure c.55 m long (Nave and Presbytery) by $30 \mathrm{~m}$ wide (North and South Trancepts) (Hockey, 1970). This raises several interesting questions. What stones were used in the abbey and what happened to the stones following the dissolution? The limited information regarding the types of stone present suggests as might be expected that the principal stone used came from the Binstead Quarries. However, there is no direct evidence as to how much of the fabric was constructed from the shelly Quarr Stone facies and how much of Binstead Limestone. The general, the paucity of the shelly Quarr Stone facies in older buildings throughout the island suggests that despite its evident quality as a freestone, it was principally exported for use on the mainland, most notably for $11^{\text {th }}$ and $12^{\text {th }}$ century stonework of Winchester Cathedral (e.g. Page, 1912). The local Binstead Stone (Bembridge Limestone) appears therefore to have been the principal stone used in the abbey fabric and documentary evidence suggests that following dissolution this limestone was sold (together with stone from Beaulieu Abbey) for re-use in the construction of Henry VIII's Solent defensive forts at East and West Cowes and also, in part, in the construction of Yarmouth Castle (Hockey, 1970).

Archaeological surveys on the abbey site have found evidence of other stones used in the abbey fabric, including carved stone mouldings of Ventnor Stone (Upper Greensand Formation) and a significant amount of Purbeck Marble fragments (Hockey, 1970). Fragments of these 'imported' stone types are still visible today as beach boulders along the adjacent coastal strip.

Perhaps one of the more interesting aspects of the use of Quarr Stone is its presence in the surviving Norman remnants of the churches of the island. These churches comprises a small group of examples in which parts of the original Norman stonework still survive all of which are invariably constructed of Quarr Stone (Yaverland, Shalfleet, Quarr, Calbourne). The later stone fabrics of these churches are in contrast constructed of a range of other local stones, confirming that wider access to the Quarr Stone facies, even within the island, was always restricted from earliest times.

The most common building limestone quarried from the Bembridge Formation is, therefore the Binstead or Bembridge Stone (named depending on the vicinity from which it was quarried) with its distinctive open vuggy layers and fossil casts. This lithology is particularly common in the older $19^{\text {th }}$ century stone buildings of Ryde and 
East Cowes. Norris Castle (1799), for example, has a mixture of both Bembridge Limestone and cross-bedded Palaeogene sandstone stonework (Newell, 2010 pers. comm.). The mortar work of the castle also has an unusual but very distinctive fine flint shard galletting within the mortar work.

Easy access to the sea meant that both the Bembridge and Quarr stones in this eastern part of the island were readily exported to the mainland. Both appear in buildings over a wide geographical area. The Quarr shelly limestones are found in variable quantities in many mainland medieval churches (Little Sonborne, Headborne Worthy, Tichborne Hinton Ampner, Corhampton, Boarhunt, Fareham, Titchfield (Hampshire) and Bosham and Sompting (Sussex)), abbeys (Beaulieu, Hyde, Romsey, Titchfield), priories (Lewes and Christchurch), cathedrals (Winchester and Chichester). Quarr Stone has also been recorded in the medieval military architecture at Portsmouth, Portchester and Southampton forts / castles (e.g. Jope, 1964) and in the surviving medieval walls and buildings of Southampton (Shore, 1908). In the western part of the island between Calbourne and Thorley the Bembridge limestone was also extensively worked for building stone (e.g. the Prospect quarries). The limestones from these quarries were used locally in Yarmouth from where it could also be easily exported to the mainland.

The use of the limestones Bembridge Limestone Formation on the mainland is known to date back to Roman times and was recorded at, for example, Fishbourne Palace near Chichester (Williams, 1971). Archaeological studies of the roofing materials used in several Roman villa sites of the island suggest that Bembridge limestone was also used for the production of roofing slates and examples can be seen on display at the Brading Roman Villa site on the island (Tomalin, 1987).

\section{Petrography of the Palaeogene building stones}

\section{Quarr Stone}

The pale-grey or buff coloured, freshwater limestone known as Quarr Stone or Featherbed Stone because of the distinctive cross-bedded, shelly-rich fabric it exhibits comprises broken and abraded thin-walled mollusc fragments with sporadic very fine sand-grade quartz grains. In many of the specimens examined in thin section the shell fragments show little or no internal structure, having been extensively replaced by ferroan spar-calcite or, only survive as neomorphic, acicular envelopes with a leached, open central core (Plate $2 \mathrm{G}$ ). Its coarse-grained nature and texture suggests 
deposition in a comparatively high energy setting as a shoal or bank. Proximity to a shoreline is also suggested by the abundance in some samples of sub-rounded to angular, detrital quartz grains.

Bembridge Limestone or 'Binstead Stone' (s.l.)

Petrographically, a wide range of facies variations are evident in the limestones of the Bembridge Limestone Formation. This thick-bedded lacustrine and palustrine succession of grey to off-white limestones commonly shows a range of features from coarsely vuggy (commonly with Chara sp.), micritic, brecciated, peloidal, fine and coarsely bioclastic limestones to bioturbated and concretionary lithologies (e.g. Armenteros et al 1997; Plate 2G). Very fine sand to silt-grade quartz and feldspar occurs ubiquitously, in lenses, patches or are dispersed within these limestone frameworks (Plate $2 \mathrm{H})$.

\section{Pleistocene building stones}

The poorly consolidated superficial sediments that comprise much of the Pleistocene successions of the island were an important local source of flint and/or chert pebbles and cobbles for building purposes. Flint walling is common feature in some villages and towns e.g. Ventnor and Bonchurch. It is used either as cobbles in the round, or as fractured cobbles in which the paler grey-brown, lustrous, internal face is revealed, or as dressed or knapped and squared stones. The flints are commonly bedded in mortar in coursed or random patterns (Plate $1 \mathrm{~F}$ ). Occasionally ferruginous, cemented blocks (ferricretes; Lamplugh 1902) from these local gravels (elsewhere in Hampshire commonly termed 'Heathstones') can be seen in some wall fabrics.

\section{Imported building and decorative stones}

Until comparatively recent times the import of building stone from the mainland for use on the island appears to have been very limited.

\section{Portland Stone}

Perhaps surprisingly, despite the close proximity of the famous Portland quarries, producers of the distinctive white ooidal and bioclastic limestones from the Upper Jurassic succession of Dorset, very little of the stone appears to have been imported to the island. The stone was used for the carved decorative stone work in Appuldurcombe House in the early $18^{\text {th }}$ century (Jones, 2000). A good example of its typical use in the $19^{\text {th }}$ century is seen in the classical façade of the HSBC Bank at 
Ryde, but few other examples are present, with the exception of a number of war memorials and sculptural objects.

Although many of the great houses of the Isle of Wight are characterised by the use of local building materials well into the $19^{\text {th }}$ century, there is one prominant exception Queen Victoria's Osborne House. Designed and constructed between 1845 and c.1851, by Prince Albert and Thomas Cubitt, the latter was best known as a major house builder in London and was responsible for much of the suburban villa architecture of Belgravia and Bloomsbury (Hobhouse 1995). This Victorian house, in Italianate style, is an architectural curiosity in the island. Some of the latest building techniques were used in its construction but only limited use was made of local materials. The house is a constructed of brick with an iron framework and smooth, plaster 'stucco' façade and although the IOW has a long local brick-making tradition, and was in fact an important exporter of bricks to the mainland, there is no clear evidence that locally made bricks were much used in the construction of Osborne House. There are several brick-making pits surrounding the estate in the Bembridge Marls but these appear to have been principally used to provide drainage pipework. By the mid- $19^{\text {th }}$ century the island had also became a major cement producer, notably from kilns sited along the Medina River and cement produced here was certainly used in the construction of Osborne House (Fenn 2008). Some natural stone was used internally, however, with 'Portland Stone' imported from the coastal quarries at Swanage chosen for paving and staircases. Penrhyn Slates from North Wales were also selected for the roof (Hobhouse 1995).

\section{Purbeck 'Marble'}

In contrast, however, the decorative 'marbles' of the early Cretaceous Purbeck succession can be widely seen across the island. Probably the best display of imported Purbeck Marble is in the Norman church at Shalfleet. Here, the large supporting columns of the nave roof comprise drums of the marble at least $0.45 \mathrm{~m}$ across and 0.30 thick. The church also contains a large Purbeck Marble font and a tombstone or leger. Purbeck Marble shaft bases are also found at Arreton church. Other examples of the marble include the large tombstone legers, now badly worn, at Godshill church. Purbeck Roofing Slate

There are several examples in higher status buildings of the Isle of Wight of the use of thick, heavy, fossiliferous limestone slates imported from the Isle of Purbeck as 
roofing material. Examples can be seen in Mottistone Manor, Wolverton Manor, West Court Manor, King James Grammar School in Newport, Brighstone Church and at Carisbrooke Castle (e.g. Brinton 1987; Tomalin 2003). In general, where present, the heavy Purbeck slates form a narrow strip along the eaves of the roof.

\section{Alabaster}

The creamy-brown, alabaster tomb effigies at Godshill Church of Sir William Worsley, which date back to the mid-16th century, are probably the best examples of the use of this distinctive Triassic decorative stone on the island. The principal source and centre for the mining and carving of alabaster (gypsum) was at Chellaston between Derby and Nottingham. Alabaster blocks were quarried in these mines from the thick gypsum beds within the Mercia Mudstone Group from medieval times, and locally carved into prestigious funereal ornaments which were distributed throughout the UK and Europe (Young 1990).

\section{The future of the Isle of Wight's stone buildings}

Today, as elsewhere in many parts of the UK, most if not all of the local building stones quarried and used in the Isle of Wight are no longer produced. This has resulted in significant concerns for both heritage conservation and new build programmes in the island. The need for replacement stone for conservation repair of not only its better known heritage buildings such as Mottistone Manor and Carisbrooke Castle, but also for the hundreds of smaller stone buildings in its towns and villages will inevitably grow over time. Even the best quality building stones can eventually decay and fail and will need to be replaced. It would be prescient of the local planning and conservation authorities in the island to consider safeguarding access to local stone resources now. The Isle of Wight's local character and distinctiveness is unique, and is very much a combination of its spectacular landscapes and distinctive built environments. Without new indigenous sources of stone for conservation repair and, equally importantly for new build projects, the island may become a less attractive place for its many visitors and residents.

\section{Acknowledgments}

This paper is published with the permission of the Executive Director of the Bristish Geological Survey. Many thanks to Pete Hobson and the rest of the BGS Isle of Wight mapping team for their guidance and congenial company during my field visits 
to the island. The buildings expertise of my wife Beryl was also invaluable both in the

field examination and interpretation of many of the buildings, and also in contributing to the final text. I would also like to thank Dr Eric Robinson for his review and perceptive comments on the manuscript.

\section{References}

Anderson, F.W. \& Quirk, R.N. 1964. A Note on the Quarr Stone. In Jope, E. H. The Saxon building stone industry in Southern and Midland England. Medieval Archaeology, 8, 115 -118.

Armenteros, I., Daley, B. \& Garcia, E. 1997. Lacustrine and palustrine facies in the Bembridge Limestone (late Eocene, Hampshire Basin) of the Isle of Wight.

Palaeogeography, Palaeoclimatology, Palaeoecology. 128, 111-132.

Colvin, H.M., Summerson, J. , Biddle, M., Hale, J.R. \& Merriman, M. 1982.

History of the King's Works. Volume 1V 1465-1660 (Part II).

Brinton, M. 1987 (compiler). Farmhouses and cottages of the Isle of Wight. Isle of Wight County Council.

Bristow, H.W., Reid, C. \& Strachan, A. 1889. The Geology of the Isle of Wight $\left(2^{\text {nd }}\right.$ Edition). Memoir Geological Survey of Great Britain .

Curry, D., Adams, C.G., Boulter, M.C. \& others. A correlation of Tertiary Rocks in the British Isles, Geological Society of London, Special Report No.12.

Daley, B. 1999. Hampshire Basin: Isle of Wight Localities. In Daley, B. \& Balson, P. British Tertiary Stratigraphy, Geological Conservation Review Series, 15, 85-151.

Fenn, R.W.D. 2008. Bardon Vectis - an outline of the history of quarrying and brick making on the Isle of Wight until 1939 (Part 1).

Hobhouse, H. 1995. Thomas Cubitt Master Builder. Management Books 2000. Ltd.

Hockey, S.F. 1970. Quarr Abbey and its Lands 1132-1631. Leicester University Press.

Hopson, P. M. et al this volume.

Insole, A. Daley, B \& Gale, A. 1998. The Isle of Wight. Geologist Association Guide No.60.

Jones, J. 2000 Castles to Cottages: The Story of Isle of Wight Houses. Wimborne: Dovecote Press 
Jukes-Browne, A. J. \& Hill, W. 1900. The Cretaceous Rocks of Britain, Volume 1: The Gault and Upper Greensand of England. Memoir of the Geological Survey of Great Britain.

Jope, E.M. 1964. The Saxon building-Stone Industry in Southern and Midland England. Medieval Archaeology VIII, 91-118.

Lamplugh, G.W. 1902. Calcrete. Geological Magazine, 9, 575.

Lewis, S. 1848. A Topographical Dictionary of England. S. Lewis \& Co. London.

Lloyd, D \& Pevsner, N. 2006. The Isle of Wight. The Buildings of England Series. Yale University Press. New Haven and London

Mantell, G. 1847. Geological Excursions around the Isle of Wight, and along the adjacent coasts of Dorsetshire; illustrative of the most interesting geological phenomena and organic remains. London: H. Bohn.

Page, W. 1912. Quarrying. pp.462-463 In Victoria County History of Hampshire and the Isle of Wight.

Potter, J.F. 2006. A geological review of some Hampshire Anglo-Saxon Churches. Proceedings of the Hampshire Field Club Archaeological Society. 61, 134-152.

Robinson, E. 1998. Building Stone: The true story of Quarr. Geology Today, MayJune

Shore, T.W. 1908. Geology and Hampshire Industries. Pp. 23-28, in T.W. Shore Memorial Volume Part 1, Minns, G.W. (ed). Printed for the Hants Field Club and Archaeological Society.

Tatton-Brown, T.W.T. 1980. The use of Quarr Stone in London and East Kent. Medieval Archaeology, 24, 213-15.

Tatton-Brown, T.W.T. 1990. Building Stone in Canterbury c.1070-1525. Pp.In Parsons, D. (ed) Stone Quarrying and Building in England AD 43-1525. Phillimore, Chichester.

Tatton-Brown, T.W.T. 1993. Building Stones of Winchester Cathedral. Pp 37-46, In Crook, J. (ed) Winchester Cathedral Nine Hundred Years 1093-1993.

Tomalin, D. J. 1987 Roman Wight; a guide catalogue. Isle of Wight County Council, Newport.

Tomalin, D. J. 2002 'Wihtgarasbyrig Explored'. Proceedings of the Isle of Wight Natural History and Archaeological Society, 18, 55-80.

Tomalin, D. J. 2003 From Gat Cliff to Carisbrooke Castle: a medieval quarry relocated. Proceedings of the Isle of Wight Natural History and Archaeological Society, 19, 101-108. 
White, H.J.O. 1921. A short account of the geology of the Isle of Wight. Memoir Geological Survey of Great Britain.

Williams, J.H. 1971. Roman building-materials in south-east England. Britannia, 2. 166-95.

Winter, C W R 1984. The Manor Houses of the Isle of Wight. Wimborne:

Dovecote Press

Young, J. 1990. Alabaster. Matlock: Derbyshire Museum Service. 


\section{Figure captions}

Figure 1. Simplified geological map of the Isle of White

Figure 2. Simplified geological vertical succession for the Isle of Wight

\section{Plate Captions}

\section{Plate 1}

A. Shorwell Cottages. Large and small blocks, variegated, intricately coursed, rubblestone sandstone blocks from the local Ferruginous Sands Formation. Window surrounds of local brick. Quoins of Bembridge Limestone.

B. Freshwater Village. Barn constructed of uncoursed, dark, ferrugenous rubblestone sandstone blocks from the Monk's Bay Sandstone Formation (Carstone).

C. Niton Village. Large, coursed, and galletted, irregular blocks of pale greenish grey, sandstone from the Upper Greensand Formation.

D. Shanklin. Wallstones and window dressings of large ashlar blocks of glauconitic sandstone from the local Upper Greensand Formation.

E. Brighstone. Large irregularly shaped, coursed and galletted chalk blocks from the local Chalk Group succession.

F. Calbourne. Coursed flint nodules with dressings of Bembridge Limestone.

G. Ventnor. Green Ventnor Sandstone (Upper Greensand Formation) ashlar facing with coursed flint cobbles on side walls.

H. Newbridge. Large and small, irregular, galleted blocks of coursed Bembridge Limestone.

\section{Plate 2.}

Thin section photomicrographs. Note all images taken at the same scale giving a field of view of $8 \mathrm{~mm}$ from left to right across the images. The sections have all been impregnated with blue resin to fill natural pores and stained for carbonate and Kfeldspar identification.

A. Fine-grained, ferrugenous, sandstone - Ferruginous Sands Formation

B. Medium- to coarse-grained, pervasively iron cemented (brown), sandstone Monk's Bay Sandstone Formation (Carstone).

C. Fine-grained, glauconitic, sandstone - Upper Greensand Formation.

D. Fine-grained, silica cemented, spicular, sandstone - Upper Greensand Formation.

E. Non-ferroan, coarsely bioclastic Purbeck Limestone - Carisbrook Castle Roofing Slate (courtesy of the National Trust)

F. Bioturbated, fine-grained non-ferroan (pink stained) micritic limestone lacustrine facies, Bembridge Limestone Formation.

G. Porous micritic, freshwater limestone abundant microfossils including Chara $s p$.

H. Coarsely bioclastic, marginal marine, limestone, non-ferroan (pink stained) with extensive secondary macroporosity following leaching out of unstable ferroan calcite bioclasts - Quarr Stone or Featherbed Stone. 
Figure 1

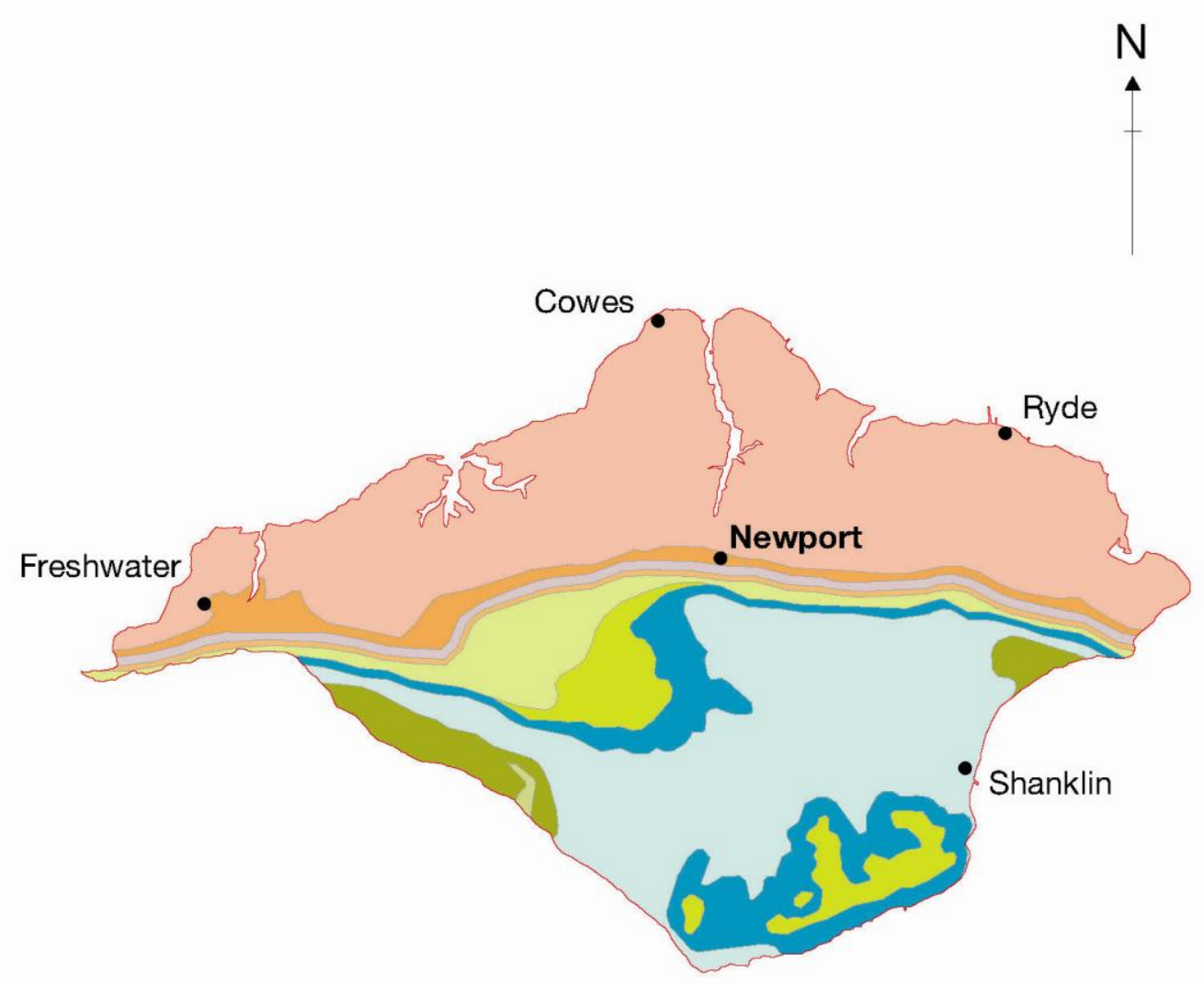

Isle of Wight Bedrock Geology

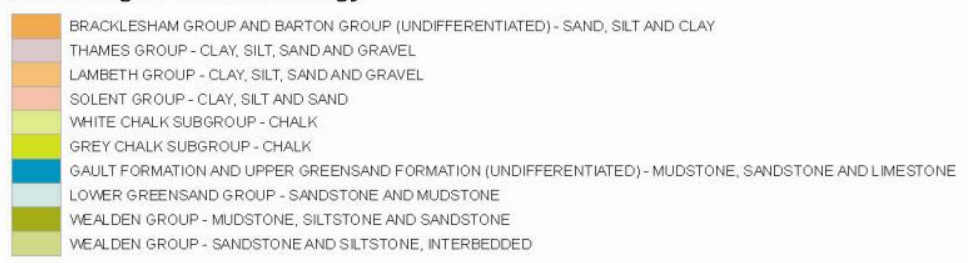

49

50

51

52

53

54

55

56

57

58

59

60

61 
Figure 2

1

2

3

\section{BUILDING STONE SOURCES OF THE ISLE OF WIGHT}

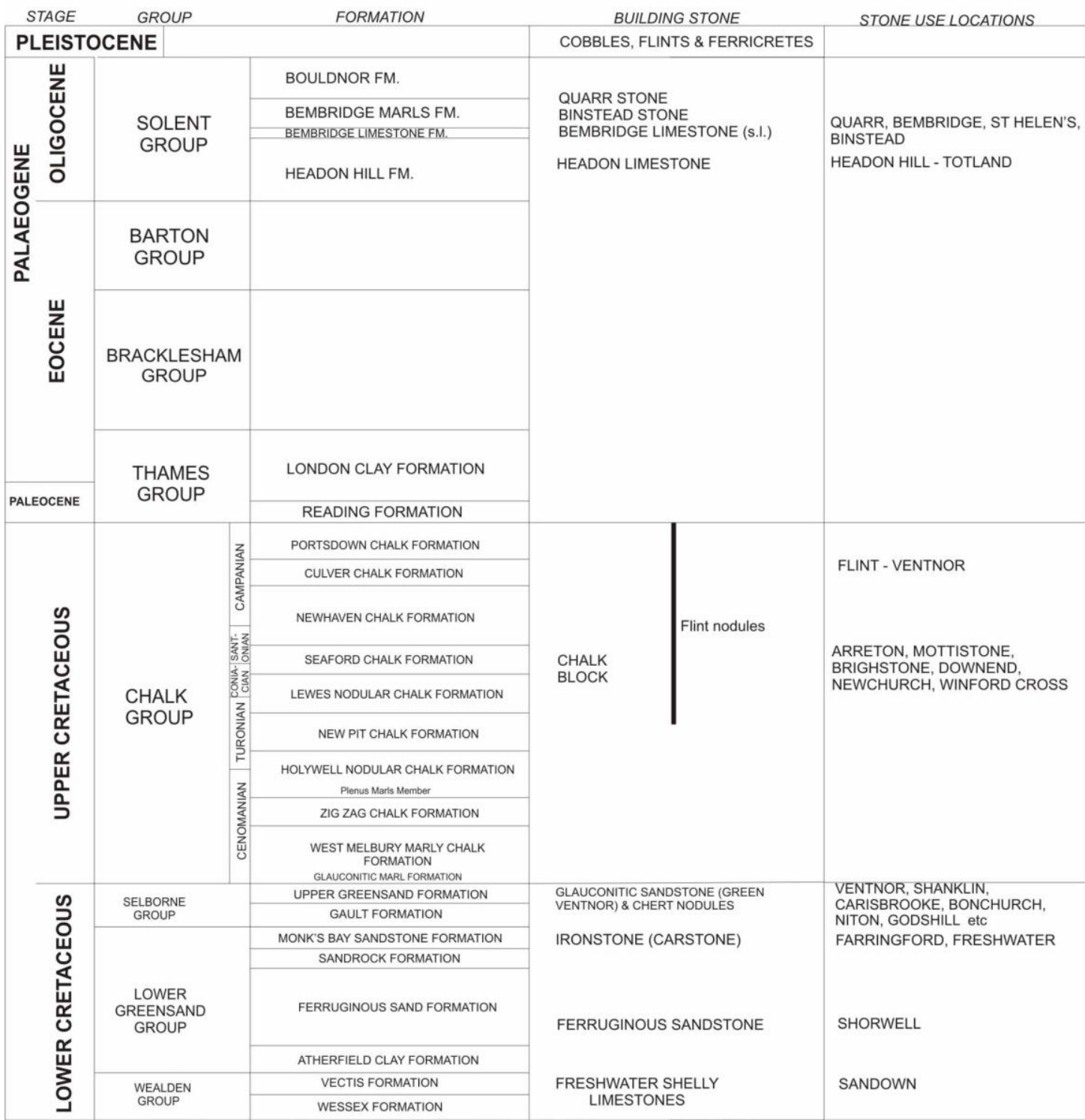

